\title{
Thoracic Aortic Aneurysm Revealed by Haemoptysis on a 10-Year-Old Girl at Paediatrics Department of Yalgado Ouedraogo University Hospital
}

\author{
Chantal Zoungrana Ouattara1, Caroline Yonaba ${ }^{1}$, Angèle Kalmogho', Flore Ouédraogo', \\ Chantal Bouda' ${ }^{1}$, Ousseini Diallo ${ }^{2}$, Ludovic Kam ${ }^{1}$ \\ ${ }^{1}$ Departement de Pédiatrie, Centre Hospitalier Universitaire Yalgado Ouédraogo, Ouagadougou, Burkina-Faso \\ ${ }^{2}$ Departement d'imagerie Médicale et Radiodiagnostic, Centre Hospitalier Universitaire Yalgado Ouédraogo, Ouagadougou, \\ Burkina-Faso \\ Email: zangele2001@yahoo.fr
}

How to cite this paper: Ouattara, C.Z., Yonaba, C., Kalmogho, A., Ouédraogo, F., Bouda, C., Diallo, O. and Kam, L. (2017) Thoracic Aortic Aneurysm Revealed by Haemoptysis on a 10-Year-Old Girl at Paediatrics Department of Yalgado Ouedraogo University Hospital. Open Journal of Pediatrics, 7, 13-17.

https://doi.org/10.4236/ojped.2017.71002

Received: December 24, 2016

Accepted: February 7, 2017

Published: February 10, 2017

Copyright $\odot 2017$ by authors and Scientific Research Publishing Inc. This work is licensed under the Creative Commons Attribution International License (CC BY 4.0).

http://creativecommons.org/licenses/by/4.0/

\begin{abstract}
Thoracic aortic aneurysm is a rather rare disorder in children and difficult to diagnose. It is generally linked to congenital heart defects or connective-tissue diseases. Our case is a 10-year-old girl admitted in the pediatric emergency care unit on January 19th, 2015 for massive haemoptysis and severe anaemia. Examination revealed severe anemia and a silent left lung. The Chest X-Ray revealed an abnormal mass on the upper left side of the mediastinum, and left lower lobe consolidation. The thoracic CT scan highlighted a $64 \mathrm{~mm}$ aneurysm of the subisthmic aorta with a thin $5 \mathrm{~mm}$ hole. It also showed pseudocoarctation of the aorta. Treatment in intensive care consisted of blood transfusion and iron supplement. She was due to travel abroad for cardio vascular surgery, but died on November 2016. Thoracic Aortic Aneurysm in our setting was discovered incidentally. In spite the fact that it is an extreme surgical emergency, in Burkina Faso, treatment can only be possible abroad upon medical evacuation.
\end{abstract}

Keywords

Aorta, Aneurysm, Haemoptysis, Coarctation, Burkina Faso

\section{Introduction}

An aortic aneurysm is a stretched and bulging section in the wall of the aorta. There are two types of aortic aneurysms: thoracic aortic aneurysms and abdominal aortic aneurysms [1]. The thoracic aortic aneurysm is rare in children and 
difficult to diagnose; it is generally associated with congenital heart defects or connective-tissue diseases. The global incidence is not known, however the scientific literature reports few cases [2] [3] [4]. Our study reports a thoracic aortic aneurysm revealed by a haemoptysis on a 10 -year-old girl, in the pediatric department of Yalgado Ouédraogo University Hospital.

\section{Observation}

A 10-year-old girl was admitted in pediatric emergency care unity on January 19th, 2015 for massive haemoptysis and severe anaemia. She had a one year history of recurrent headache, chest pain, and haemoptysis. The haemoptysis episode which led to hospitalization was massive, with severe anaemia and dizzinesses.

Medical history: Pregnancy and birth were normal with no history of neonatal resuscitation, cyanosis, or respiratory distress syndrome. Her immunization charts were up to date and complied with the national immunization schedule for the age. She had normal weight and height growth. Her psycho-social development was also normal.

Family history revealed that, she was the 4th child of the family of 6 children; there was no parental consanguinity; her mother suffered from numbness (following childhood meningitis); her 4-year-old brother died recently from unknown cause.

\section{Physical examination noted:}

- patient conscious, in bad condition with very pale skin and in good nutritional state.

- vital signs: pulse $124 \mathrm{p} / \mathrm{mn}$, respiratory rate $22 \mathrm{c} / \mathrm{mn}$, blood pressure: $100 / 50$ mmHg on the right arm, weight: $24 \mathrm{~kg}$, height: $129.5 \mathrm{~cm}$, BMI: $14.31 \mathrm{~kg} / \mathrm{m}^{2}$.

- cardiovascular examination: shock, a systolic murmur grade IV on the lower axillairy line in the 5th left intercostal space, irradiating to the armpit.

- lung examination: a decrease of breath sounds on the left lung.

Laboratory tests: blood test confirmed severe anaemia (haemoglobin: 3.6 $\mathrm{g} / \mathrm{dl})$

- blood tests in search of bacterial infections were negative, blood urea, creatinine, and glycemia were normal.

- sputum culture for the tuberculosis infection was also negative.

Front Chest X-Ray highlighted a dense left para hilar mass in the mediastinum (Figure 1) and left lung consolidation (Figure 2).

Echocardiography showed no heart defects, subisthmic aortic aneurysm measuring $64 \mathrm{~mm}$ diameter.

Thoracic CT scan showed more details of the abnormalities: complexe malformation of aortic trunks: aberrant sub clavian arteries, a subisthmic aortic aneurysm $(64 \mathrm{~mm})$ with a $5 \mathrm{~mm}$ narrow opening, and a pseudocoarctation of the aorta (Figure 3). The left lung consolidation was probably associated with pneumonia or lung sequestration.

Treatment consisted of red blood cells transfusion. She died on November 


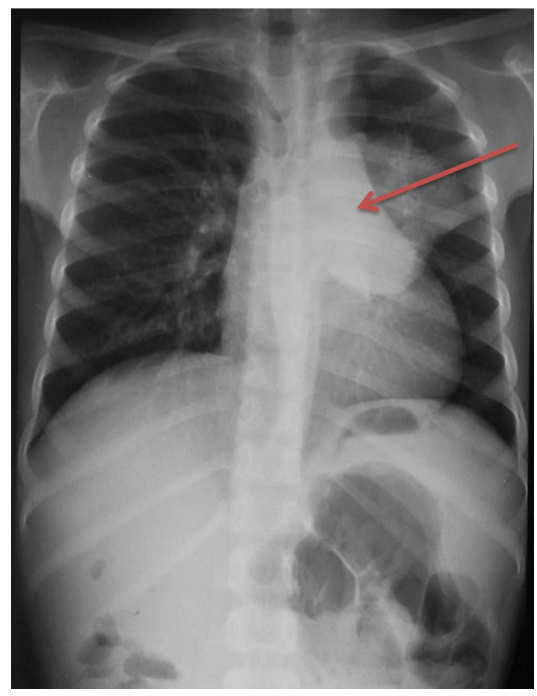

Figure 1. Front chest X-ray: dense para hilar mass in the left mediastinum.

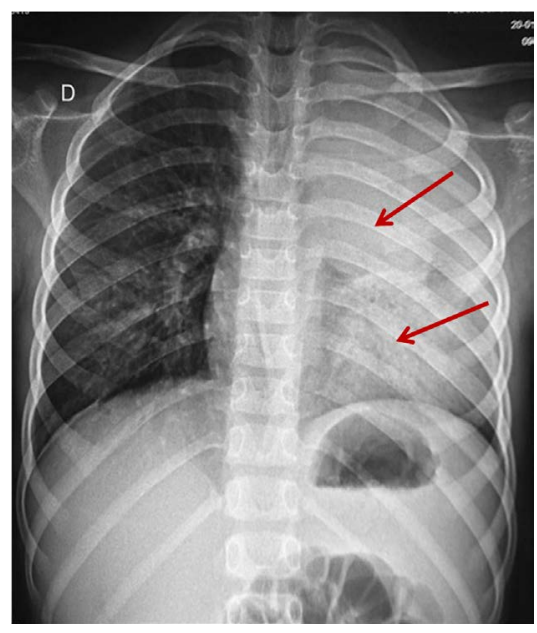

Figure 2. Front chest X-ray: dense para hilar mass and pneumonia (two months after).
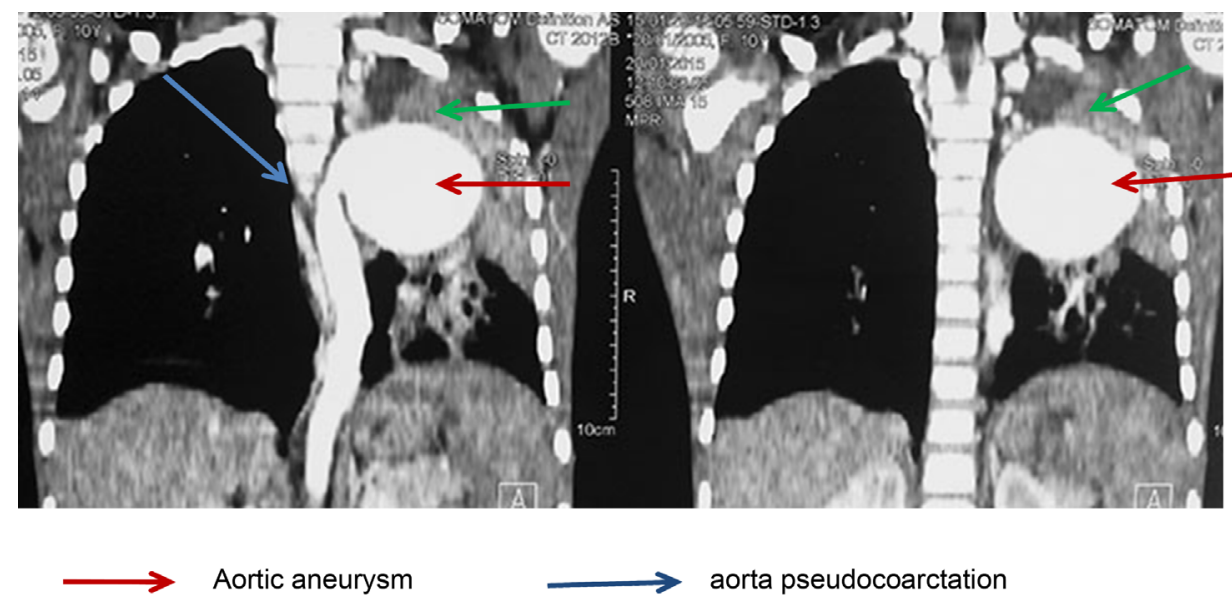

\section{lung pneumonia probably associated with a lung sequestration}

Figure 3. Thoracic CT scan: Aortic aneurysm and aorta pseudocoarctation. 
2016, from severe haemoptysis. She was still on a waiting list for medical evacuation abroad for cardiovascular surgery.

\section{Discussion}

Thoracic aortic aneurysm is rare in children [5]; few cases have been reported in the scientific literature. Abdominal aortic aneurysm is the most common. Most aneurysms are associated with other disorders like connective-tissue diseases: Marfan syndrome, Ehler-Danlos syndrome, Loeys-Dietz syndrome, Bourneville's disease [4], or cardiovascular pathologies such as hypoplastic left heart syndrome [3], sternal cleft [2] [5], aortic stenosis [6], bicuspid aortic valve [4], aortic coarctation [5] [6]. However, abdominal aortic aneurysm can also be caused by an infected umbilical catherism [7]; aneurysm of tuberculosis and mycosis origin has also been reported [8] [9] [10]. Our patient had several vascular defects: pseudocoarctation of aorta and aberrant sub clavian arteries.

Our patient was 10 years old at the time of the diagnosis. We found no data in the scientific literature specifying the mean age at the time of diagnosis in children.

Clinical symptoms are not specific: epigastric or chest pain, vomiting, aerophagia [3] [11] [12]; most aneurysms are discovered incidentally when screening for malformation. The risk here is when they bust or leak [3]. In our setting, treatment was a challenge as heart surgery is not available in the country. The nature of the aneurysm could only be specified after surgery, unfortunately the patient died before the surgery and it was not possible to perform post mortem lab tests.

\section{Conclusion}

Thoracic aortic aneurysm in our working setting was discovered incidentally. In Burkina Faso, in spite the fact that the condition can be potentially life-threatening, cardio vascular surgery is only possible abroad. The implementation of a vascular surgery unit is necessary in order to improve the prognosis of this disease and other cardiovascular diseases in children.

\section{References}

[1] US National Library of Medicine: Aortic Aneurysm. https://medlineplus.gov/aorticaneurysm.html

[2] Padalino, M.A., Stellin, G., Thiene, G., Rubino, M., Rizzo, S., Milanesi, O. and Basso, C. (2010) Giant Congenital Aortic Aneurysm with Cleft Sternum in a Neonate: Pathological and Surgical Considerations for Optimal Management. Cardiovascular Pathology, 19, 183-186. https://doi.org/10.1016/j.carpath.2008.12.003

[3] Stolla, M., Sweeney, A., Alfieris, G.M. and Metlay, L.A. (2014) Aortic Aneurysm with a Ruptured Dissection in a 15-Year-Old Boy with Hypoplastic Left Heart Syndrome. The Journal of Thoracic and Cardiovascular Surgery, 147, e35-e36. https://doi.org/10.1016/j.jtcvs.2013.11.034

[4] Zanotti, G., Vricella, L. and Cameron, D. (2008) Thoracic Aortic Aneurysm Syndrome in Children. Seminars in Thoracic and Cardiovascular Surgery. Pediatric 
Cardiac Surgery Annual, 11-21. https://doi.org/10.1053/j.pcsu.2008.01.005

[5] Hirata, Y., Arkovitz, M.S., Marboe, C.C. and Mosca, R.S. (2009) A Successful Neonatal Repair of Congenital Aortic Aneurysm with Cleft Sternum. The Journal of Thoracic and Cardiovascular Surgery, 137, 769-771. https://doi.org/10.1016/j.jtcvs.2008.06.037

[6] Picarelli, D., Antunez, S., Kreutzer, C., Touyá, G., Abdala, D., Ligüera, L. and Echegaray, G. (2007) Thoracic Aortic Aneurysm in a Young Infant with Congenital Aortic Stenosis. The Journal of Thoracic and Cardiovascular Surgery, 133, 1098-1099. https://doi.org/10.1016/j.jtcvs.2006.12.018

[7] Dhahbi, M., Souei Mhiri, M., Mrad Dhali, K., Hasni Bouraoui, I. and Monastiri, K. (2005) Anévrysme de l'aorte abdominale du nouveau-né et nourrisson: Présentation de 2 cas. European Journal of Radiology, 65-69.

[8] Ye, C., Yin, H., Lin, Y., Zhou, L., Ye, R., Li, X., Han, A. and Wang, S. (2012) Abdominal Aorta Aneurysms in Children: Single-Center Experience of Six Patients. Annals of Thoracic Surgery, 93, 201-205.

https://doi.org/10.1016/j.athoracsur.2011.08.038

[9] Mechchat, A., Idrissi, R., El Mahi, O., Lekehal, B., Sefiani, Y., Mesnaoui, A., Ammar, F. and Bensaid, Y. (2008) Multiple Tuberculous Aortic Aneurysms in a Child. A Case Report. Journal Des Maladies Vasculaires, 33, 218-220. https://doi.org/10.1016/j.jmv.2008.09.006

[10] Le Noir, B., De Nino, W.F., Bradley, S.M. and Kavarana, M.N. (2015) Mycotic Aortic Aneurysm in a Child with Aortic Coarctation. The Journal of Thoracic and Cardiovascular Surgery, 149, e44-e46. https://doi.org/10.1016/j.jtcvs.2014.11.043

[11] Clark, N. and Brener, B.J. (1998) Abdominal Aortic Aneurysm in a Young Child: A 25-Year Follow-Up Study. Journal of Vascular Surgery, 28, 715-717. https://doi.org/10.1016/S0741-5214(98)70100-4

[12] Marín-Manzano, E., González-de-Olano, D., Haurie-Girelli, J., Herráiz-Sarachaga, J.I., Bermúdez-Cañete, R., Tamariz-Martel, A., Cuesta-Gimeno, C. and Pérez-deLeón, J. (2009) Idiopathic Thoracic Aortic Aneurysm at Pediatric Age. Annals of Vascular Surgery, 23, 258.e19-e21. https://doi.org/10.1016/j.avsg.2008.08.028

Submit or recommend next manuscript to SCIRP and we will provide best service for you:

Accepting pre-submission inquiries through Email, Facebook, LinkedIn, Twitter, etc. A wide selection of journals (inclusive of 9 subjects, more than 200 journals)

Providing 24-hour high-quality service

User-friendly online submission system

Fair and swift peer-review system

Efficient typesetting and proofreading procedure

Display of the result of downloads and visits, as well as the number of cited articles

Maximum dissemination of your research work

Submit your manuscript at: http://papersubmission.scirp.org/

Or contact ojped@scirp.org 